\title{
OVER GEREEDSCHAP EN VAKMANSCHAP
}

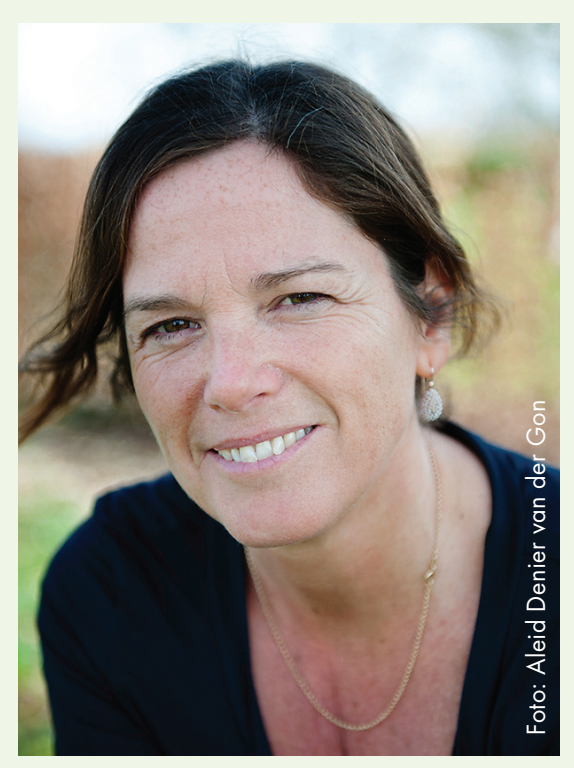

In dit nummer vindt $u$ drie artikelen over de ontwikkeling van instrumenten om problemen in kaart te brengen en te klassificeren. Mooi vind ik dat. Een goed instrumentarium kan professionals ondersteunen in hun werk. Immers, net zoals de tuinman of de timmerman, heeft ook de vakman (of vakvrouw natuurlijk) in de jeugdhulp behoefte aan deugdelijk gereedschap. Met alle veranderingen in de jeugdhulp komen de professionals steeds meer onder druk te staan. Behandelingen moeten korter en gericht zijn op de vragen van de jeugdigen en haar ouders. Tegelijkertijd moet de hulp integraal zijn. Maar hoe krijgen behandelaren in korte tijd goed inzicht in de precieze aard van de klachten en zorgen en houden ze tegelijkertijd zicht op de bredere context waarin de problemen zich voordoen? Instrumenten kunnen daarbij helpen. Nooit als vervanging van het klinisch oordeel, maar als ondersteuning daarvan. Bijvoorbeeld omdat je met behulp van een vragenlijst een nog completer beeld krijgt van problemen. Tirsa van der Velden en haar collega's laten zien dat de Sensory Profile, afgenomen naast een vitgebreide ontwikkelingsanamnese en een gestructureerde observatie met de ADOS, in de diagnostiek van kinderen met een stoornis vit het autismespectrum toch nog extra en bruikbare informatie oplevert over de manier waarop deze kinderen zintuiglijke prikkels verwerken.
De bijdrage van Tamara de Beuf toont hoe de START:AV kan helpen om kansen en risico's op een gestructureerde manier in kaart te brengen. Zeker als het gaat om jongeren met complexe problemen zoals je die vaak ziet binnen een residentiële setting, is dat belangrijk. Het instrument kan de behandelaar aanknopingspunten bieden voor het kiezen van interventies, maar het kan ook gebruikt worden om veranderingen te evalueren.

De CAP-J, beschreven in het artikel van Willeke Daamen, is een taxonomie, een classificatiesysteem om problemen op vijf domeinen (psychosociaal functioneren, lichamelijke gezondheid, cognitieve ontwikkeling, gezin en opvoeding en de omgeving van de jeugdige) te benoemen. Zo'n instrument helpt professionals dezelfde taal te spreken. Een belangrijk punt als we willen dat kennis uit verschillende gebieden van de jeugdhulp bij elkaar komt, met andere woorden: als we integraal moeten werken.

We zijn het er wel over eens dat instrumenten om allerlei redenen nuttig gereedschap zijn in het klinische werk. Mooi dus dat onderzoekers en behandelaars werken aan de ontwikkeling van goede instrumenten. Toch is een kritische noot op $z^{\prime} n$ plaats. Om van waarde te zijn in de praktijk moeten de instrumenten voldoen aan minimale kwaliteitseisen: validiteit, betrouwbaar- heid en norm- of referentiegegevens - u weet wel, dat soort dingen. Ik heb nog eens gekeken in de NJI-databank waarin op dit moment 128 instrumenten zijn opgenomen. Deze databank biedt helaas geen mogelijkheid om te zoeken op deze kwaliteitseisen. Maar gebaseerd op een kleine (en eerlijk gezegd willekeurige steekproef) vermoed ik dat er op dit gebied nog veel werk te doen is.

Daarnaast vind ik dat er in de klinische praktijk veel te weinig aandacht is voor het leren gebruiken van instrumenten. Hoe lees je de gegevens? Wat betekenen ze precies? Hoe ga je om met tegenstrijdige informatie en hoe bespreek je de vitkomsten zo dat ze ook voor de cliënt herkenbaar en waardevol zijn? Dat kan in de praktijk nog knap lastig zijn.

Om nog even terug te komen op de vergelijking met gereedschap. Gereedschap moet van goede kwaliteit zijn. Maar daarmee ben je er niet. Alleen een vakman kan dat gereedschap op de juiste manier gebruiken, het juiste gereedschap inzetten bij de juiste vraag en eventueel gereedschappen met elkaar combineren. Bovendien moet niet alleen gereedschap, maar ook de kunde van de vakman goed worden onderhouden. Dat kost tijd, maar het loont!

Marike Serra, hoofdredacteur van Kind en Adolescent Praktijk, werkt als adviseur bij Accare Kinder- en Jeugdpsychiatrie. 